\title{
ENGLISH AS LINGUA FRANCA AND ASEAN ECONOMIC COMMUNITY (AEC): A PERSPECTIVE OF ISLAMIC ECONOMY FACULTY IN BUILDING STRONG MUSLIM STUDENTS IN IAIN BUKITTINGGI
}

\author{
Widya Syafitri \\ Institut Agama Islam Negeri (LAIN) Bukittinggi \\ e-mail:widyasyafitri260780@gmail.com \\ Febria Sri Artika \\ Institut Agama Islam Negeri (LAIN) Bukittinggi \\ e-mail:febria.artika80@gmail.com
}

\begin{abstract}
Since English was declared as lingua franca and also because more foreign companies established in Indonesia, so mastering English is becoming one of the most important preparations for the Indonesian nation to face AEC (ASEAN Economic Community). This article aimed to explore about the importance of English for Moslem students in AEC preparation, Moslem students' English competency for struggling AEC, and to see curriculum concern on fulfilling the need of Moslem students relate to AEC. This research was developed qualitatively. It was found that learning English is very crucial for Moslem students since AEC has started. However, their English competency has not been balanced with the need because IAIN Bukittinggi has just implemented English in two semesters only. It is not sufficient to meet the need of Islamic Economic human resources challenges AEC.
\end{abstract}

Keywords: Lingua franca, Moslem students, Asian Economic Community

\section{Abstrak}

Semenjak bahasa Inggris dideklarasikan menjadi bahasa pengantar atau bahasa Lingua Franca dalam perdagangan bebas ASEAN, juga karena semakin banyaknya perusahaan asing berdiri di Indonesia setelah diberlakukannya pasar bebas, menyebabkan menguasai bahasa Inggris menjadi salah satu persiapan penting bagi bangsa Indonesia untuk menghadapi MEA (Masyarakat Ekonomi Asean). Artikel ini bertujuan untuk mengupas tentang pentingnya bahasa Inggris dalam persiapan menghadapi Masyarakat Ekonomi Asean. Tulisan ini juga bertujuan untuk melibat kemampuan bahasa Inggris mahasiswa Islam terkhusus di IAIN Bukittinggi serta ingin mengetabui apakah kurikulum yang diterapkan di IAIN Bukittinggi sudah memenubi kebutuban mahasiswa terkait persiapan mereka menyambut MEA. Penelitian ini dilakukan dengan metode deskriptif kualitatif. Dari hasil penelitian menunjukkan babwa bahasa Inggris sangat penting bagi mahasiswa Muslim dalam menghadapi MEA. Namun kemampuan bahasa Inggris mereka belum untuk memenubi tantangan MEA, bal ini disebabkan karena bahasa Inggris hanya dipelajari dalam dua semester selama perkuliahan Strata 1.

Kata Kunci: Lingua franca, Mahasiswa Muslim, Masyarakat Ekonomi Asean.

\section{Background}

ASEAN (Association of South-East Asian Nations) was established on a deal of five countries in Southeast Asia, namely Indonesia, Philippines, Thailand, Malaysia and Singapore, on 8 August 1967 in Bangkok ${ }^{1}$. Until now ASEAN has developed and attracted to 5 (five)

1 Sri Handayani, 'Pentingnya Kemampuan Berbahasa Inggris Sebagai Upaya dalam Menyongsong Asean Community 2015', Jurnal Profesi Pendidik, 3.1 (2016), 102-6. other countries, such as Brunei, Laos, Cambodia, Brunei, and Vietnam.

ASEAN has been a gateway to the global economy for industrial and business activities in the ASEAN region. From 2015, Indonesia and Southeast Asian countries have adopted an ASEAN economic community or better known as the ASEAN Economic Community (AEC). Other specialists also refer to the ASEAN free market. A community, in terms of economics, emphasizes the establishment of 
a single market and bringing together aspects of social culture ${ }^{2}$.

ASEAN Economic Community or known as AEC is a crucial milestone in ASEAN economic integration agenda that has the purpose of eliminating, or, minimise barriers in conducting economic activities across the region, such as investments, in the trade of goods, and services. In other words, in Southeast Asia will appear free trade, which causes easy entry of goods, services or professional personnel from neighbouring countries.

AEC is conducted in order to Asean's competitiveness increases and can oppose China and India to attract foreign investments. In this region, foreign investment is required to elevate employment and improve welfare. ${ }^{3}$ The establishment of a single market, the Asean Economic Community will enable one country to sell goods and services easily to neighbour countries throughout Southeast Asia so that the competition is getting more rigid.

The main purpose of AEC 2015 is implemented through the 4 (four) main pillars, namely; ASEAN as a mono-market and the international free flow elements based production of investments, goods, services, educated workforce and more free the flows of capital; ASEAN as a high economic competitiveness district, with elements of engagement regulation, customer protection, and intellectual premises rights, infrastructure expansion, taxation, and e-commerce; ASEAN as an area with decent economic progress with small and average enterprise upgrowth elements, and ASEAN integration

${ }^{2}$ Asean Secretariat Team, "A Blueprint for Growth ASEAN Economic Community 2015: Progress and Key Achievements", (Jakarta: ASEAN Secretariat, 2015), p. 21

${ }^{3}$ Muhammad Bagus Ainun Najib, 'Pro Kontra Pasar Bebas ASEAN MEA di Indonesia', in Kompasiana $<$ https://www.kompasiana.com/muhammadbagusainu nnajib/55531005739773570cfa2ba0/pro-kontra-pasarbebas-asean-mea-di-indonesia $>$ [accessed 5 May 2018]
Initiative for CMLV countries (Cambodia, Myanmar, Laos, and Vietnam); and ASEAN as a fully integrated area with the global economy with a coherent element of approach in economic relationships outside the region, and increasing participation in global production networks.

For Indonesia, AEC became an early stage to develop various economic qualities in Southeast Asia in the development of the free market at the end of 2015. AEC is becoming a good chance since trades barriers may tend to diminish and become un present too. It will affect on improving the export that is going to upgrade Indonesia's Gross Domestic Product (GDP) eventually. AEC, however, being the two-sided currency for Indonesia: One side, this is a good opportunity to demonstrate the quality and quantity of Indonesian products and human resources to other countries, but on the other side it can be Boomerang for Indonesia If Indonesia cannot make good use of it.

In case of investment, this condition can bring a climate which leads the inclusion of FDI or Foreign Direct Investment that enable stimulate the growth of economic by technological developments, job making, human resources development also easier admittance to the world market.

With this free trade, we are able to increase the exports but we also have to be aware of the risk of the competition that appears with the total of imported things which will continuity in huge amount to Indonesia. It will make the threat to Local industries to battle with far more qualified overseas products. It is going to ultimately breakthrough the trade balance loss for our country, Indonesia.

In point of investment, Indonesia still possesses fewer compulsory regulatory level as to create a large scale exploitation action to the chance of natural resources by nondomestic companies entering Indonesia on the point of 
a territory that sufficient with natural resources compared to other pastorals. Not covered by the feasibility of taking advantage of foreign companies can blemish the ecosystem of Indonesia, whereas the investment rule in our country has not been powerful enough in preserving natural situation as the possibility of normal resources included.

On the employment field, it has a huge chance for job seekers because there will be large numbers of works with various needs for dissimilar skills. In addition, admission to go overseas in consideration of looking for work becomes accessible even it can be with no particular barrier. AEC is also an awesome occasion for entrepreneurs to find the best workers based on the expected requirement.

But it can bring about employment risks for Indonesia. For education and productivity, our beloved country still loses the competition with Malaysia, Singapore, and Thailand workforce along with the industry basic for Indonesia itself to make Indonesia still get at fourth rank in ASEAN.

The existing problems of the Labor side can not be separated from the low quality, such as the level of education and expertise that have not been adequate. From ILO data, Indonesia's population, mostly Muslims, in August 2014 amounted to 252.7 million people with a total workforce of 121.9 million. However, this cannot be balanced with the quality of education owned by the employees. The majority of Indonesian workers are still elementary school educated and more working in the informal sector. An Islamic Economic lecturer stated,

"MEA belum menguntungkan Indonesia karena bangsa Indonesia belum siap menghadapinya dan Indonesia dijadikan sebagai market potential bagi negara lain seperti Singapura."

${ }^{4}$ Mr. Yuarman Mansur, an Islamic Economic lecturer of IAIN Bukittinggi, Indonesia, Interview, 15 May 2019
The lecturer explained that AEC is unprofitable for Indonesian since they are not ready to deal with it and Indonesia still become a potential market for newly industry country, like Singapore.

Actually, Indonesia should see AEC as an open opportunity to improve existing Human resources by enhancing competitiveness, providing adequate education and health, and educate the importance of AEC 2015.

The purposes of the establishment of the Islamic Economic Community focuses not only on the single market, in terms of economic but also embrace the social and cultural aspects. It means that the implementation of AEC is not only limited to exchange activities but also the exchange of service personnel or human resources ${ }^{5}$. As the largest citizen, Indonesian Muslims must also be prepared with the present condition. In order to compete in this AEC era, every Muslim must-have skill. Without adequate skills, it is argued that the enforcement of AEC can be an unforeseen threat. This should be a consideration for the Indonesian people to develop themselves to be ready to face AEC.

Facing this free market, there will be many established foreign companies. Thus, one of the skills must have is English mastery. While Arabic, German and Chinese become additional skills. But if the individual is able to speak more than one language, it can be said that the individual has added value in competing in the AEC era. Language is a compulsory communication tool in the face of free markets such as AEC. Because it is said that globalization is like a country without Borders. $^{6}$

5 Iskandar, 'Pentingnya Bahasa Inggris di Era Globalisasi', Portal-Ilmu, 2.1 (2016), 26-39.

${ }^{6}$ Team, 'Kesiapan Masyarakat Indonesia Menuju MEA', Suara Jakarta < http://suarajakarta.com kesiapan-masyarakat-indonesia-menuju-masyarakatekonomi-asean-2015> [accessed 15 May 2018] 
The use of international language instruction such as English is already widespread, especially for aspiring entrepreneurs and job seekers. Mastering English has become a must for them to keep up with the times. As we know that English is the most widely used language. When the presidents of this world meet, the English language will be the connecting language. Especially for people who work in foreign companies, they must have good English speaking competency.

In the ASEAN region, the use of English has been declared as a lingua franca. The Lingua Franca is a language used for people who come from a variety of different language backgrounds in communicating, both oral and written communication. Able to speak English actively can be a capital for Indonesian Muslims to succeed in entering the AEC.

It is found three great reasons why English must be mastered by Indonesian Muslims. First, due to English is as the media in seeking knowledge. With good English skills, Indonesian Muslims will easily understand new knowledge in certain areas. The second reason, because English can help someone to get a more decent job. Many companies both national and foreign companies that require prospective employees to be able to communicate with English that is marked with a TOEFL certificate. The third, that is to be able to promote agricultural products to the international community, especially in the ASEAN region.

Concerning to AEC or Asean Economic Community, this article is discussing the readiness of Indonesian English ability to encounter AEC and also about building a strong Indonesian Muslim in Islamic economy perspective. The methodology applied is a qualitative method using descriptive analysis and literature review. The data are gained from secondary data, and also through observation and interview.

\section{Encountering Asean Economic Community (AEC)}

The short story of ASEAN and ASEAN Economic Community

As a previous explanation, the Association of Southeast Asian Nations (ASEAN) was developed through the ASEAN Declaration on 8 August 1967 in Bangkok, Thailand. The declaration was signed by five countries: Indonesia, Philippines, Malaysia, Thailand and Singapore. So these five countries are referred to as the Founding Fathers. But the next year some other countries also joined. Such as Brunei Darussalam, Vietnam, Myanmar, Laos and Cambodia. Until now, ASEAN members numbered 10 countries.

Meanwhile, the idea of forming AEC is realized long-term roadmap model named Hanoi Plan of Action in 1998. AEC position in lieu of ASEAN Free Trade Area (AFTA).

Meanwhile, the idea of forming AEC is realized in the form of long-term roadmap named the Hanoi Plan of Action in 1998. AEC position in lieu of ASEAN Free Trade Area (AFTA).

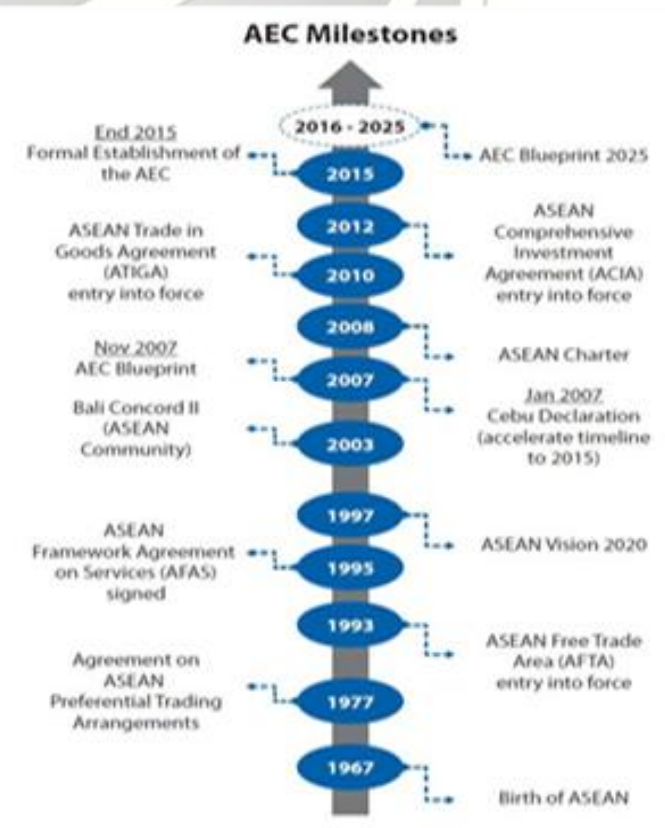

Figure 1. Illustration of the establishment of ASEAN on 8 August 1967 until AEC's enactment on 31

December 2015 


\section{The Readiness of Indonesian English Competency}

The general language used in a global transaction in English. Thus, there is, of course, a strong correlation between English competency and some indicators related to the economy. Some observers, however, doubt the readiness of the Indonesian nation to face the AEC, because they feel the Indonesian nation does not have adequate English capability at the ASEAN. Surely this statement is concluded from the results of comprehensive reports. Referring to the English report of the EF English Proficiency Index (EF EPI) in 44 countries conducted by the EF World Education Institute, Indonesia occupies the $34^{\text {th }}$ position. $^{7}$ This outcome is ironic in comparison with our neighbouring country, Malaysia, which is in 9th place. The ability to communicate with an international language, the Indonesian nation is far behind from this neighbouring country which is a rival country in the free market AEC 2015. Seeing such phenomena is not unlikely that the nation of Indonesia will be a slave in their own country if the government and the nation of Indonesia do not attempt to increase its human resources in this short time. This research finding was in line with STP Mataram students' English skill that was not ready to face $\mathrm{AEC}^{8}$.

It's a serious problem that can't be crossed. Thus, the Indonesian Government should be able to encourage the training of skills because the majority of Indonesian workers are lacking in English proficiency. It is necessary to improve the training of English language skills that are not only limited knowledge but also intensive and applicative nature so that it can be used in everyday life.

7 Permana Heri, Peningkatan Kemampuan Berbahasa Inggris dengan Konsep 'Kota Inggris' Menyambut MEA 2015, Kompasiana <http:/ / kompas.com> [accessed 25 Februari 2018]

${ }^{8}$ Ida Nyoman and Tri Darma, 'The Readiness of English Communication Skills of Mataram Tourism Vocational College Students for Asean Economic Community', Economic, 5 (2018), 40-53.
The strategy to be taken by the Indonesian Government must certainly be correlated with what has been recommended in the pillars of the AEC Blueprint 2015 which requires each ASEAN state to reform all key elements that are the absolute requirement in encountering the implementation of AEC 2015. This Era demands strong competitiveness in the areas of technology, management, and human resources, including English mastery.

Theoretically, this demand should be also met by the students of Islamic Economic Faculty Students of IAIN Bukittinggi. Unfortunately, their ability has not been enough to struggle with this demand. It was proved that only $30 \%$ of students were able to do communication well and fluently in their task of interviewing someone. The rest students only read their transcript. That's a serious problem for higher education, especially for English lecturer to overcome.

\section{The Importance of English for Muslims in encountering ASEAN Economic Community}

Since the ASEAN Economic Community (AEC) has been started, Indonesians Muslim have to be ready about the challenging of all sectors in life; economic, politic, cultural, educational, and so forth ${ }^{9}$. English will be one of the keys to succeed in facing AEC, due to in social-cultural aspect; Moslems need to communicate with other citizens from ASEAN countries. Thus English is the most powerful means to establish this connection.

Islam has taught the Moslems to be experts in economic development as a tool to achieve its vision in building a multicultural Indonesia ${ }^{10}$. Human resources are the key to

${ }^{9}$ Nanik Shobikah, 'The Importance of English Language in Facing Asean Economic Community (AEC)', At-Turats, 11.1 (2017), 85-93.

10 Supriono - Supriono, 'Islam and the Asean Economic Community (Aec): A Perspective of Islamic Economy in Building a Multicultural Society in Indonesia', Addin, $10.2 \quad$ (2016), 263 <https://doi.org/10.21043/addin.v10i2.1160>. 
success in dealing with AEC, not a country's wealth or a per capita income. By applicable to AEC, the opportunity to get the job will decrease because of competition with the best graduates from all over Southeast Asia who participated in the labour market in Indonesia. So it will be found many unemployment, high poverty rate, and social gaps in Indonesia.

Every Indonesian Muslim is required to be a strong and reliable resource especially in the field of communication. English as an international language must be mastered by every individual either in technology-based communication or communicating directly.

Table 1. Indonesian Moslems and AEC

\begin{tabular}{|l|l|l|l|l|}
\hline $\begin{array}{l}\text { Strongly } \\
\text { Agree }\end{array}$ & Agree & Fair & Disagree & $\begin{array}{l}\text { Strongly } \\
\text { disagree }\end{array}$ \\
\hline $60 \%$ & $40 \%$ & 0 & 0 & 0 \\
\hline
\end{tabular}

Source: Interview to Indonesian Moslems about the importance of English to face AEC

Table 1 above emphasizes that Indonesian Muslims must be ready to compete with the neighbouring countries by mastering English. The Muslim generation of Indonesia must be able to speak English both oral and written. Some previous researches, such as in Islamic Boarding School, also revealed the efforts done by the school to equip the students to face the free market. As done by Insan Cendikia Boarding School (ICBS) Payakumbuh. ${ }^{11}$

This boarding school provides students with English Fortnight. The school obligates its students to use English in their daily life for two weeks a month. This program aims at preparing the students to encounter AEC and can go international. It is also in line with another program such as student exchange to Japan.

The above research is also in line with a survey conducted by one of the IPBF students.

11 Artika, Febria Sri dan Widya Syafitri, Pengembangan Materi Pembelajaran Bahasa Inggris Berbasis Kecakapan Hidup (Life Skill) di Pesantren Insan Cendikia Boarding School Guna Mewujudkan Eksistensinya Sebagai Pesantren Bilingual, \{Unpublished Research Paper, LP2M IAIN Bukittinggi, 2018\}, p. 20
This student concludes about how important English language skills a student should have after graduation in improving competitiveness.

In this era of globalization, facing Asean Economic Community (AEC), every individual from ASEAN countries will compete in various jobs. Thus, besides mastering our own language, the Indonesian language, Indonesian Muslims really need to master English. How can a Muslim win a business competition with neighbouring countries, if language problems are still constrained? How can Indonesian Muslims be able to promote their products and explain the advantages of Indonesian culture if Indonesian Muslims still have problems with communication?

As table 1 state $60 \%$ respondents feel that English is very important. But some researchers find Indonesian Moslem got a problem to English mastery. This communication problem should be a serious problem for the government of Indonesia which should be immediately formulated a solution. Singapore state, Malaysia, the Philippines and other ASEAN countries will be the main rivals because of this international language. To prepare for a reliable and proficient Muslim-speaking generation, the government has issued policies related to training to improve English proficiency.

\section{English as Lingua Franca}

English is the most popular language studied as the official introductory language of 42 countries in the world. In addition, English also serves as an influential international introductory language. 


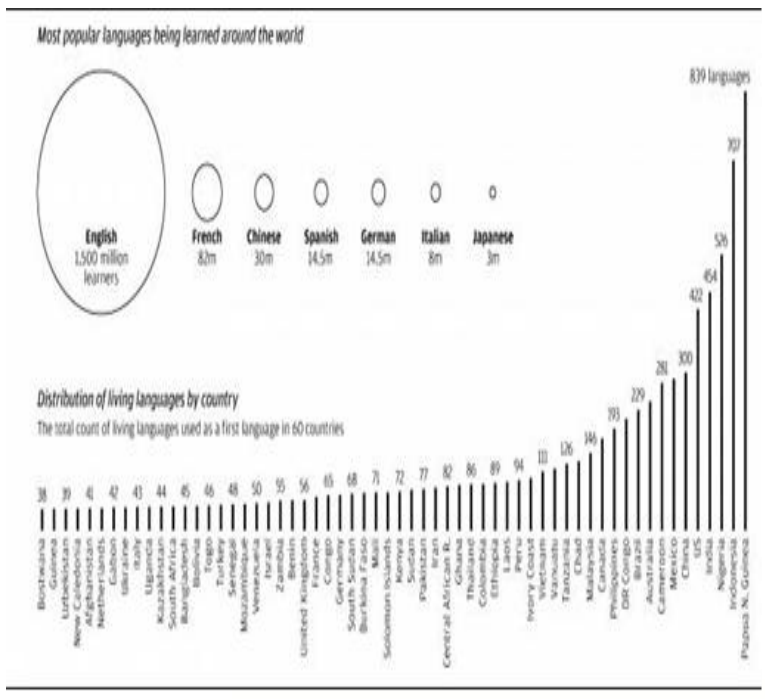

Figure 2. English is the most popular language to learn compared to 839 languages around the world

It is known that English become the most influential language in the world, one in five people in the world is able to speak or perhaps at least she or he can understand what someone says in English.

In this world, English is used in three circles, namely the inner circle, the outer circle and the expanding circle. The countries included in the inner circle are the United Kingdom and the United States, Canada, Australia and New Zealand that make the English as mother tongue. While the outer circle is the countries that make English as a second language. Such as Singapore, Hongkong, Malaysia, India and Filipina. And the last one is the expanding circle. Expanding Circle is of which English is as a foreign language. Like for Indonesia, Myanmar, Thailand, Cambodia, China, and Russia.

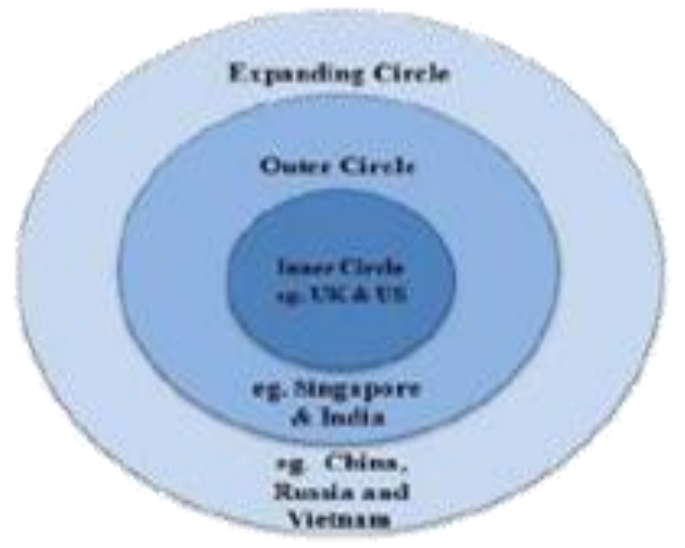

Figure 3. Three circles of the Englishspeaking countries

The countries incorporated in ASEAN have their own language. Like Indonesia, has Bahasa Indonesia as the language of the confirmation. Malaysia has the Malay language and others. But since 2009 and emphasized in the 13th ASEAN SUMMIT held in Singapore, ASEAN countries have agreed that English becomes the de facto lingua franca. The most important moment in this SUMMIT is the declaration of the establishment of the Asian Economic Community (AEC). Thus, in 2015, English was officially an ASEAN language.

It can be concluded that mastering English is a necessity for Indonesian workers who will compete in the ASEAN region. Where the manpower in the ASEAN region will compete in eight professional areas that have been signed during the year 2005 to 2008 . Beginning in 2005, the approved profession is engineering services, then nursing services in the year 2006, Architectural Service and survey qualification in 2007, last in 2008, there are four professions are signed that is medical Practitioners, dental practitioners, tourism services and accounting services.

Based on the results of the interview on the importance of Indonesian Muslims must speak English, it can be deduced several points: the first as a media in search of science. So many resources that use English can be 
taken advantage of. By mastering or having adequate English skills, one will easily gain new knowledge according to their field.

The second reason, having good English skills can help someone get a decent job or match the level. Because having adequate English skills can be a worthy value for someone. Moreover, nowadays there are many foreign companies operating in Indonesia, which will certainly apply the English language as the language of the Precourse. Some national companies now also require prospective workers to have a specific TOEFL and IELTS level. It is conceivable that graduates do not have good English proficiency, have failed the administration before starting the test at more levels. That means they are considered incapable of competing with other prospective workers.

The third reason, English can help a person even country in promoting Indonesian products in the international arena. But unfortunately, based on the results of the research, Indonesian language proficiency in the ASEAN region is in the score range 38.45 - 54.06, or entry very low category. This score is equivalent to the English language proficiency score of Vietnam and Thailand.

\begin{tabular}{|c|c|c|c|}
\hline Rank & Country & Score & Level \\
\hline 9 & Malaysia & 55.54 & High Proficiency \\
\hline 12 & wong Kong & 54.44 & Moderate Proficiency \\
\hline 13 & - South Korea & 54.19 & Moderate Proficiency \\
\hline 14 & a Japan & 54.17 & Moderate Proficiency \\
\hline 25 & " Taiwan & 48.93 & Low Proficiency \\
\hline 26 & Saudi Arabia & 48.05 & Low Proficiency \\
\hline 29 & China & 47.62 & Low Proficiency \\
\hline 30 & India & 47.35 & Low Proficiency \\
\hline 32 & = Russia & 45.79 & Low Proficiency \\
\hline 34 & Indonesia & 44.78 & Very Low Proficiency \\
\hline 39 & In Vietnam & 44.32 & Very Low Proficiency \\
\hline 42 & Thailand & 39.41 & Very Low Proficiency \\
\hline
\end{tabular}

Figure 4. English proficiency scores of several ASEAN countries ${ }^{12}$

${ }^{12} \mathrm{~K}$. Breene, "Which Countries are Best at English as a Second Language?", Weforum
Figure 5. Rankings, scores and levels of English proficiency of ASEAN countries
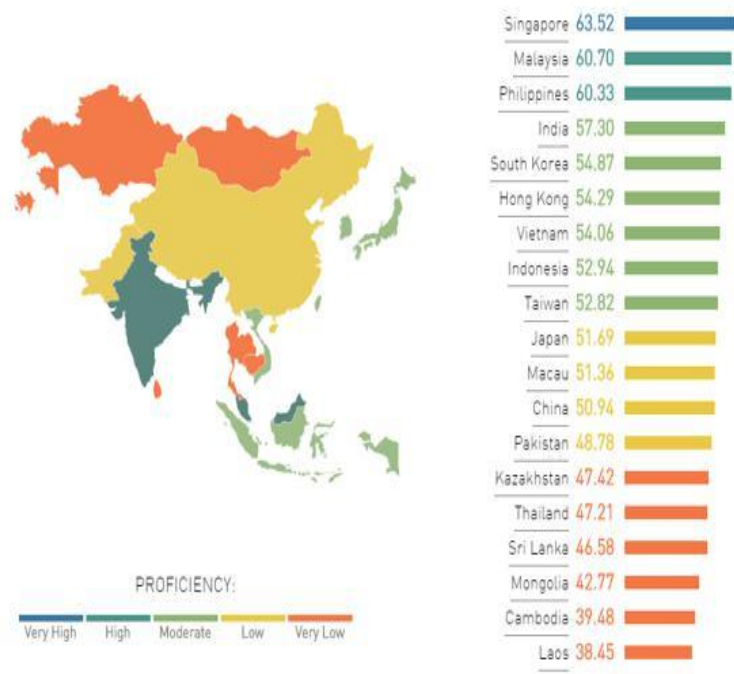

English Practices for AEC's Preparation

Based on the research finding, one form of English language implementation to face AEC is the presence of an English village. Indonesia's most famous Kampong of English is located in Pelem and Tulungrejo village, Pare District, Kediri Regency, East Java. This Kampong of English is arguably successful because it already has hundreds of foreign language course institutions that are well known in Indonesia as well as overseas, international level. This Kampong has spawned graduates who are fluent in English, although only studying in a matter of days. Students can easily absorb all of their studies. This can happen because the environment supports it. The environment in this area supports English speaking in everyday life. Like Ojeg, rice stalls, even the entire villagers are instructed to use English as their colloquial language.

In addition to Pare, the Kampung Inggris (English Village) is also found in Bandung.

<https://www.weforum.org/agenda/2016/11/wh ich-countries-are-best-at-english-as-a-secondlanguage-4d24c8c8-6cf6-4067-a753-> [accessed 5 Sept 2018] 
The course is called Wisdomnesia English or British Saung. The Saung's presence depicts public awareness of the importance of English in answering challenges and future competition. The British Saung also aims to improve communication skills on the ASEAN scale as well as internationally. In West Sumatera, there are two villages implement the English Kampong. It is in Lawang and Harau, 50 Kota district.

For the equality of English proficiency in Indonesia, this Kampung Inggris (English Village) should not only in Pare or in Bandung. Not everyone has the opportunity and the ability to study in the Kampung Inggris (English Village) in Pare or in Bandung. Most of the study system in English Village Pare uses the quota system, so not everyone who is interested and comes there can learn. Indonesia's economy is believed to be increasing when big cities in Indonesia can apply the concept of English Kampong. Because it can absorb labour, automatic unemployment will be reduced.

One form of improvement of Indonesia's development infrastructure is by increasing human resources in the field of language. Due to infrastructure development is not only limited to physical but also the skill of its people. Muslim Indonesians believe that establishing a full-fledged English course with the government will make the community enthusiastic to learn and feel that this English is a necessity in welcoming the AEC. Especially if the course institutions apply the Applicative method of the community area and creative integrated learning that is based on local wisdom.

\section{Islamic Economics in Building a Strong Moslems Students in IAIN Bukittinggi}

We can see the implementation of Islamic economics principle in Indonesia in daily life. As known Indonesia is not an Islamic country even though occupied by Muslims majority but the value of Pancasila basically is in line with
Islamic economic value ${ }^{13}$. We can see that most Indonesians Moslem care about Halal and Haram product and guided by the Indonesian Ulema Council (MUI). It means most Moslems will not buy something, like food, if there is no Halal label from MUI.

In another case, relate to the Asean economic community, building up human resources in several sectors is required to do. For Indonesia, strengthening the people is a must since, in China-AFTA, Indonesians only got less advantageous compared to China because of the low skilled and trained worker ${ }^{14}$.

Among the service sector, Islamic finance grows quickly in ASEAN, in the form of banking, capital market, microfinance and so forth. Such improving in Islamic finance, Indonesia needs a high quality of human recourses. It means universities; higher educations take responsibility to provide the market with skilful practitioners, expert, and workers in part of Islamic economic sectors. In this case, English plays an important role. English based content of the subject is needed to cover them with better comprehension about the current information about Islamic economic which mostly informed in English.

In Economic faculty of IAIN Bukittinggi, English is an obligatory subject followed by all students. This subject is not only studied in one semester during lecturing but until two semesters to produce reliable and professional students in their field. Concerning to observation, this number can't demand Asean Economic Community struggle. These two semesters of learning English are not enough

13 Idri and Rohaizan Baru, 'The Principles of Islamic Economics and Their Implementation in Indonesia', International Journal of Academic Research in Business and Social Sciences, 7.4 (2017), 331-44 <https://doi.org/10.6007/ijarbss/v7-i4/2809>.

14 Ahmad Darmadji and Yuli Andriansyah, 'Curriculum of Islamic Economics and Finance in Islamic University of Indonesia: Challenges of ASEAN Economic Community', Global Journal of Business and Social Science Review, 1.1 (2015), 17-24. 
to provide students with the skill and ability of English.

\section{Conclusion}

Since English has become the influential language in ASEAN Economic Community (AEC), Indonesian Moslems students must be able to master this world language. It aims to successfully compete with other countries in Southeast Asia. Government need to give full attention to Indonesians' English proficiency because of the research finding of EF EFI. It stated that Indonesia occupies $34^{\text {th }}$ position from 44 countries. Communities have tried to overcome this case by holding Kampung Inggris (English Village) in Pare and other places and also improve Indonesia's development infrastructure. Related to the curriculum of higher education, English was only learned twice in Economic Faculty of IAIN Bukittinggi. This condition was not sufficient to provide high-quality resources in Islamic economic sector. IAIN Bukittinggi needs to adopt Kampung Inggris curriculum to meet students' need in struggling AEC. In conclusion, it really needs the big support of government to achieve Indonesian Muslims students successful in facing the Asian Economic Community (AEC).

\section{References}

\section{Books}

Artika, Febria Sri dan Widya Syafitri, Pengembangan Materi Pembelajaran Bahasa Inggris Berbasis Kecakapan Hidup (Life Skill) di Pesantren Insan Cendikia Boarding School Guna Memujudkan Eksistensinya Sebagai Pesantren Bilingual, \{Unpublished Research Paper, LP2M IAIN Bukittinggi, 2018\}

ASEAN Secretariat Team, "A Blueprint for Growth ASEAN Economic Community 2015: Progress and Key Achievements", (Jakarta: ASEAN Secretariat, 2015).

\section{Journals}

Darmadji, Ahmad, and Yuli Andriansyah, 'Curriculum of Islamic Economics and Finance in Islamic University of Indonesia: Challenges of ASEAN Economic Community', Global Journal of Business and Social Science Review, 1 (2015), 17-24

Handayani, Srri, 'Pentingnya Kemampuan Berbahasa Inggris Sebagai Dalam Menyongsong ASEAN Community 2015', Jurnal Profesi Pendidik, 3 (2016), 102-6

Idri, and Rohaizan Baru, 'The Principles of Islamic Economics and Their Implementation in Indonesia', International Journal of Academic Research in Business and Social Sciences, 7 (2017), 33144 <https://doi.org/10.6007/ijarbss/v7i4/2809>

Iskandar, 'Pentingnya Bahasa Inggris Di Era Globalisasi Portal-Ilmu', 2. 1 (2016), 2639

Nanik Shobikah, 'The Importance of English Language in Facing Asean Economic Community (AEC)', At-Turats, 11 (2017), 85-93

Nyoman, Ida, and Tri Darma, 'The Readiness of English Communication Skills of Mataram Tourism Vocational College Students for Asean Economic Community', Economic, 5 (2018), 40-53

Supriono, Supriono -, 'Islam and the Asean Economic Community (AEC): A Perspective of Islamic Economy in Building a Multicultural Society in Indonesia', Addin, 10 (2016), 263 $<$ https://doi.org/10.21043/addin.v10i2. $1160>$

\section{Online references}

Breene, K., "Which Countries are Best at English as a Second Language?", Weforum $<$ https://www.weforum.org/ag enda/2016/11/which-countries-arebest-at-english-as-a-second-language- 
4d24c8c8-6cf6-4067-a753-> [accessed 5 Sept 2018]

Najib, Muhammad Bagus Ainun, 'Pro Kontra Pasar Bebas ASEAN MEA di Indonesia', in Kompasiana <https://www.kompasiana.com/muha mmadbagusainunnajib/55531005739773 570cfa2ba0/pro-kontra-pasar-bebasasean-mea-di-indonesia $>$ [accessed 5 May 2018]

Permana, Heri, Peningkatan Kemampuan Berbahasa Inggris dengan Konsep 'Kota Inggris' Menyambut MEA 2015, Kompasiana $<$ http:/ /kompas.com $>$ [acces sed 25 Februari 2018]

Team, 'Kesiapan Masyarakat Indonesia Menuju MEA', Suara Jakarta $<$ http://suarajakarta.com kesiapanmasyarakat-indonesia-menujumasyarakat-ekonomi-asean2015>[accessed 15 May 2018] 